\title{
External Auditory Canal Fistula
}

National Cancer Institute

\section{Source}

National Cancer Institute. External Auditory Canal Fistula. NCI Thesaurus. Code C124532.

An abnormal communication between the external auditory canal and the adjacent tissues. 